\title{
Growth Hormone, Glucose, and Free Fatty Acid Levels in Mother and Infant in Normal, Diabetic, and Toxaemic Pregnancies
}

\author{
Z. LARON, S. MANNHEIMER, M. NITZAN, and J. GOLDMANN \\ From the Departments of Pediatrics and Obstetrics, Tel Aviv University Medical School and Rogoff-Wellcome \\ Medical Research Institute, Beilinson Medical Center, Petah Tikva, Israel
}

Only a few investigations concerning growth hormone (HGH) levels in maternal and cord blood in humans have been made. These were limited to normal pregnancies (Greenwood, Hunter, and Klopper, 1964; Yen, Pearson, and Stratman, 1965). Though the absolute values of HGH cannot be compared in these two investigations since different methods of measuring the HGH were used, both studies found a higher concentration of $\mathrm{HGH}$ in the umbilical arterial plasma than in the umbilical venous and maternal plasma, suggesting an active secretion of HGH by the foetal anterior pituitary. This was further confirmed by the observations made by Cornblath, Parker, Reisner, Forbes, and Daughaday (1965), and Laron, Mannheimer, Pertzelan, and Nitzan (1966), who found, in newborn babies, conspicuously raised plasma growth hormone concentrations, equal to those found in acromegalic subjects.

The present investigation was designed to study the mother-infant relationship of $\mathrm{HGH}$ in diabetic and toxaemic pregnancies, about which there is no available information.

\section{Material and Methods}

Three groups of subjects were studied: women with a normal pregnancy (Table I), pregnant diabetic women (Table II), and women who developed toxaemia of pregnancy (Table III). During labour all women were routinely given an intravenous drip containing oxytocin 5 units in $500 \mathrm{ml}$. of a $5 \%$ glucose solution. Up to delivery the women usually received about $200-300 \mathrm{ml}$. Blood was drawn into heparinized tubes from the mother and cord at delivery and from the infant 2 to 4 hours later. The greater time lapse usually took place when the delivery had taken place at night. The blood was stored at $-4^{\circ} \mathrm{C}$. until centrifugation. Free fatty acids (FFA) and true glucose (GOT) were determined the same day.

Received May 17, 1966.
Plasma was stored at $-20^{\circ} \mathrm{C}$. for assay of growth hormone (HGH). The blood or plasma of the mother, cord, and infant were always analysed together, in duplicate. Free fatty acids were determined according to Dole (1956). Blood glucose was measured by the glucose oxidase method using Worthington reagents. Growth hormone was determined by radio-immunoassay, as described elsewhere (Laron and Mannheimer, 1966).

\section{Results}

The comparative concentrations of $\mathrm{HGH}$, glucose, and FFA in each mother, the cord blood, and infant, in normal pregnancies, in mothers with diabetes, and with toxaemic pregnancies, are illustrated in Fig. 1-3. The results obtained are summarized in Table IV.

Growth hormone. It is evident that the concentration of plasma growth hormone is much higher in the infant than in the mother. With few exceptions the level of plasma $\mathrm{HGH}$ in the cord lay between that in the mother and that in the infant, though in a few instances it was higher than in the infant. In the mothers with diabetes there is a greater individual variation in the plasma $\mathrm{HGH}$ than that seen in normal women, but there is no statistical difference between the two means. In the women with toxaemia, however, the mean $\mathrm{HGH}$ concentration is significantly higher $(p<0.02)$. In this group the $\mathrm{HGH}$ concentration was much higher in the cord blood $(p<0.01)$ than that in the other two groups, and higher values were also found in the infant a few hours after birth. It should be stressed that the values in the cord blood represent the mixture between maternal and infant blood at delivery, whereas the blood from the infant was taken several hours after birth, thus showing concentrations at a somewhat different time. In the infants of diabetic mothers the plasma $\mathrm{HGH}$ concentration was significantly lower than in the infants of normal mothers $(p<0.01)$. 
TABLE I

Pertinent Data of Mother and Infant in Normal Pregnancies

\begin{tabular}{|c|c|c|c|c|c|c|c|c|}
\hline \multirow{2}{*}{$\begin{array}{l}\text { Case } \\
\text { No. }\end{array}$} & \multicolumn{4}{|c|}{ Mother } & \multicolumn{4}{|c|}{ Infant } \\
\hline & Name & $\begin{array}{l}\text { Age } \\
(y r .)\end{array}$ & Parity & Delivery & Sex & $\begin{array}{l}\text { Weight } \\
\text { (g.) }\end{array}$ & $\begin{array}{c}\text { Length } \\
\text { (cm.) }\end{array}$ & $\begin{array}{l}\text { Length of } \\
\text { Gestation } \\
\text { (wk.) }\end{array}$ \\
\hline $\begin{array}{l}1 \\
2 \\
3 \\
4 \\
5 \\
6 \\
7 \\
8 \\
9\end{array}$ & $\begin{array}{l}\text { K.E. } \\
\text { D.R. } \\
\text { D.S. } \\
\text { H.H. } \\
\text { A.D. } \\
\text { Sh.R. } \\
\text { G.E. } \\
\text { W.G. } \\
\text { R.S. }\end{array}$ & $\begin{array}{l}26 \\
27 \\
31 \\
20 \\
35 \\
18 \\
34 \\
28 \\
23\end{array}$ & $\begin{array}{l}\text { II } \\
\text { II } \\
\text { II } \\
\text { II } \\
\text { I } \\
\text { I } \\
\text { III } \\
\text { II } \\
\text { I }\end{array}$ & $\begin{array}{c}\text { Spontaneous } \\
\text { Spontaneous } \\
\text { Spontaneous } \\
\text { Caesarean section } \\
\text { Caesarean section } \\
\text { Caesarean section } \\
\text { Vacuum } \\
\text { Caesarean section } \\
\text { Spontaneous }\end{array}$ & $\begin{array}{l}M \\
\text { F } \\
M \\
M \\
M \\
F \\
F \\
M \\
M\end{array}$ & $\begin{array}{l}3750 \\
3580 \\
2880 \\
3150 \\
3500 \\
3100 \\
3900 \\
3180 \\
5200\end{array}$ & $\begin{array}{l}52 \\
50 \\
54 \\
48 \\
53 \\
49 \\
51 \\
51 \\
54\end{array}$ & $\begin{array}{l}40 \\
40 \\
38 \\
39 \\
40 \\
40 \\
40 \\
38 \\
40\end{array}$ \\
\hline
\end{tabular}

TABLE II

Pertinent Data of Mother and Infant in Women With Diabetes Mellitus

\begin{tabular}{|c|c|c|c|c|c|c|c|c|}
\hline \multirow{2}{*}{$\begin{array}{l}\text { Case } \\
\text { No. }\end{array}$} & \multicolumn{4}{|c|}{ Mother } & \multicolumn{4}{|c|}{ Infant } \\
\hline & Name & $\begin{array}{l}\text { Age } \\
(y r .)\end{array}$ & Parity & Delivery & Sex & $\begin{array}{l}\text { Weight } \\
\text { (g.) }\end{array}$ & $\begin{array}{c}\text { Length } \\
\text { (cm.) }\end{array}$ & $\begin{array}{l}\text { Length of } \\
\text { Gestation } \\
\quad \text { (wk.) }\end{array}$ \\
\hline $\begin{array}{l}1 \\
2 \\
3 \\
4 \\
5 \\
6 \\
7 \\
8 \\
9\end{array}$ & $\begin{array}{l}\text { S.A. } \\
\text { K.E. } \\
\text { M.A. } \\
\text { Z.S. } \\
\text { F.G. } \\
\text { B.P. } \\
\text { L.R. } \\
\text { E.E. } \\
\text { B.N. }\end{array}$ & $\begin{array}{l}20 \\
32 \\
26 \\
28 \\
40 \\
31 \\
27 \\
22 \\
21\end{array}$ & $\begin{array}{l}\text { I } \\
\text { II } \\
\text { II } \\
\text { III } \\
\text { IX } \\
\text { II } \\
\text { III } \\
\text { II } \\
\text { I }\end{array}$ & $\begin{array}{c}\text { Caesarean section } \\
\text { Caesarean section } \\
\text { Spontaneous } \\
\text { Caesarean section } \\
\text { Caesarean section } \\
\text { Caesarean section } \\
\text { Caesarean section } \\
\text { Spontaneous } \\
\text { Spontaneous }\end{array}$ & $\begin{array}{l}\mathrm{M} \\
\mathrm{F} \\
\mathrm{M} \\
\mathrm{M} \\
\mathrm{M} \\
\mathrm{F} \\
\mathrm{M} \\
\mathrm{M} \\
\mathrm{F}\end{array}$ & $\begin{array}{l}4160 \\
3050 \\
3690 \\
3000 \\
4300 \\
4200 \\
4400 \\
4000 \\
2600\end{array}$ & $\begin{array}{l}53 \\
50 \\
54 \\
48 \\
53 \\
51 \\
53 \\
51 \\
43\end{array}$ & $\begin{array}{l}37 \\
38 \\
38 \\
37 \\
37 \\
36 \\
37 \\
40 \\
29\end{array}$ \\
\hline
\end{tabular}

TABLE III

Pertinent Data of Mother and Infant in Women With Toxaemia

\begin{tabular}{|c|c|c|c|c|c|c|c|c|}
\hline \multirow{2}{*}{$\begin{array}{l}\text { Case } \\
\text { No. }\end{array}$} & \multicolumn{4}{|c|}{ Mother } & \multicolumn{4}{|c|}{ Infant } \\
\hline & Name & $\begin{array}{l}\text { Age } \\
\text { (yr.) }\end{array}$ & Parity & Delivery & Sex & $\begin{array}{c}\text { Weight } \\
\text { (g.) }\end{array}$ & $\begin{array}{c}\text { Length } \\
\text { (cm.) }\end{array}$ & $\begin{array}{l}\text { Length of } \\
\text { Gestation } \\
\quad \text { (wk.) }\end{array}$ \\
\hline $\begin{array}{l}1 \\
2 \\
3 \\
4 \\
5 \\
6 \\
7 \\
8\end{array}$ & $\begin{array}{l}\text { G.E. } \\
\text { E.Z. } \\
\text { P.L. } \\
\text { M.D. } \\
\text { H.S. } \\
\text { A.D. } \\
\text { K.Z. } \\
\text { N.M. }\end{array}$ & $\begin{array}{l}21 \\
38 \\
24 \\
30 \\
33 \\
28 \\
25 \\
21\end{array}$ & $\begin{array}{l}\text { I } \\
\text { III } \\
\text { III } \\
\text { IV } \\
\text { I } \\
\text { II }\end{array}$ & $\begin{array}{c}\text { Caesarean section } \\
\text { Caesarean section } \\
\text { Spontaneous } \\
\text { Spontaneous } \\
\text { Spontaneous } \\
\text { Spontaneous } \\
\text { Spontaneous } \\
\text { Spontaneous }\end{array}$ & $\begin{array}{l}\mathbf{M} \\
\mathbf{F} \\
\mathbf{F} \\
\mathbf{M} \\
\mathbf{M} \\
\mathbf{M}\end{array}$ & $\begin{array}{l}1800 \\
2400 \\
3200 \\
2350 \\
4320 \\
2950 \\
3000 \\
3400\end{array}$ & $\begin{array}{l}42 \\
46 \\
50 \\
46 \\
53 \\
49 \\
49 \\
50\end{array}$ & $\begin{array}{r}30 \\
38 \\
39 \\
38 \\
40 \\
38 \\
? \\
39\end{array}$ \\
\hline
\end{tabular}

Blood glucose. All women received about 200 to $300 \mathrm{ml}$. of a $5 \%$ glucose infusion, which most probably had no significant influence on the blood glucose concentration. As compared to normal women, the concentration of blood glucose was higher in the diabetic mothers and lower in the women with toxaemia. There were no significant differences in the cord blood values. After birth the blood sugar in the infants decreased $50 \%$ or more within a few hours.
Free fatty acids. Free fatty acids in the plasma were about three times higher in the mother than in the cord blood in normal and diabetic mothers. In toxaemia the proportion was significantly lower $(p<$ 0.05 ). There was no difference between the groups in the levels of FFA in the cord plasma. In the only infant of a diabetic mother tested for FFA, the concentration was lower than in the infants of normal mothers. As shown by Fairweather (1965), oxytocin-induced labour does not affect the serum FFA concentration. 


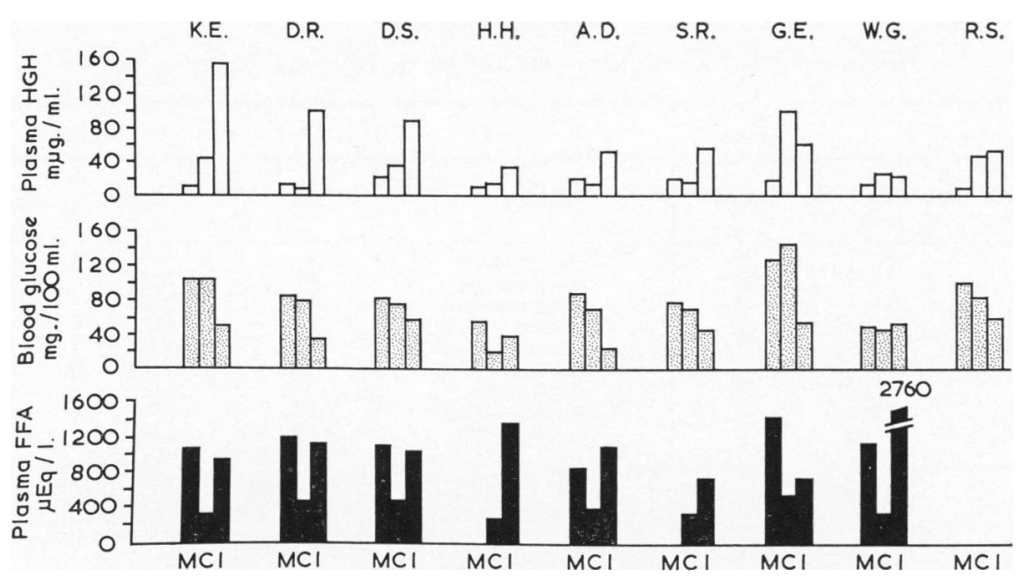

FIG. 1.-Plasma growth hormone (HGH), glucose, and free fatty acids in normal pregnant women at delivery, in the cord, and in the newborn infants.
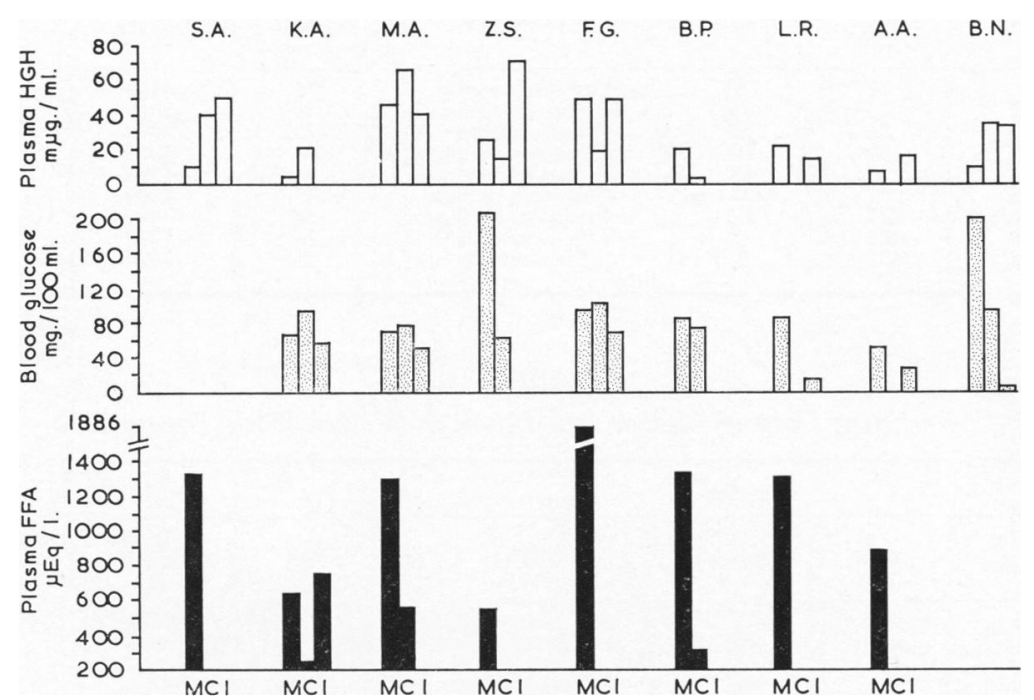

FIG. 2.-Plasma growth hormone (HGH), glucose, and free fatty acids in pregnant diabetic women at delivery, in the cord, and in the newborn infants.

TABLE

Mean Concentrations of Growth Hormone, Glucose, and Free Fatty Acids in the

\begin{tabular}{|c|c|c|c|c|c|c|c|c|c|}
\hline \multirow{3}{*}{ Group } & \multicolumn{6}{|c|}{ HGH ( $\mu \mathrm{mg} . / \mathrm{ml})}$. & \multicolumn{3}{|r|}{ Glucose } \\
\hline & \multicolumn{2}{|c|}{ Mother } & \multicolumn{2}{|r|}{ Cord } & \multicolumn{2}{|c|}{ Infant } & \multicolumn{2}{|c|}{ Mother } & \\
\hline & No. & Mean \pm S.E. & No. & Mean \pm S.E. & No. & Mean \pm S.E. & No. & Mean \pm S.E. & No. \\
\hline $\begin{array}{l}\text { Normal .. } \\
\text { Diabetic .. } \\
\text { Toxaemic .. }\end{array}$ & $\begin{array}{l}9 \\
9 \\
7\end{array}$ & $\begin{array}{l}15 \pm 1 \cdot 8 \\
21 \pm 5 \cdot 2 \\
24 \pm 3 \cdot 0^{\star}\end{array}$ & $\begin{array}{l}9 \\
6 \\
6\end{array}$ & $\begin{array}{l}34 \pm 9 \cdot 7 \\
26 \pm 8 \cdot 7 \\
93 \pm 15^{\star}\end{array}$ & $\begin{array}{l}9 \\
7 \\
7\end{array}$ & $\begin{array}{l}69 \pm 14 \\
40 \pm 7 \cdot 7 \star \\
99 \pm 42\end{array}$ & $\begin{array}{l}9 \\
9 \\
8\end{array}$ & $\begin{array}{r}90 \pm 8 \cdot 6 \\
114 \pm 24 \\
69 \pm 3^{\star}\end{array}$ & $\begin{array}{l}9 \\
6 \\
6\end{array}$ \\
\hline
\end{tabular}

No. = number of determinations. * Statistically significant difference compared to the values in the normal group. Student's $t$ test. 

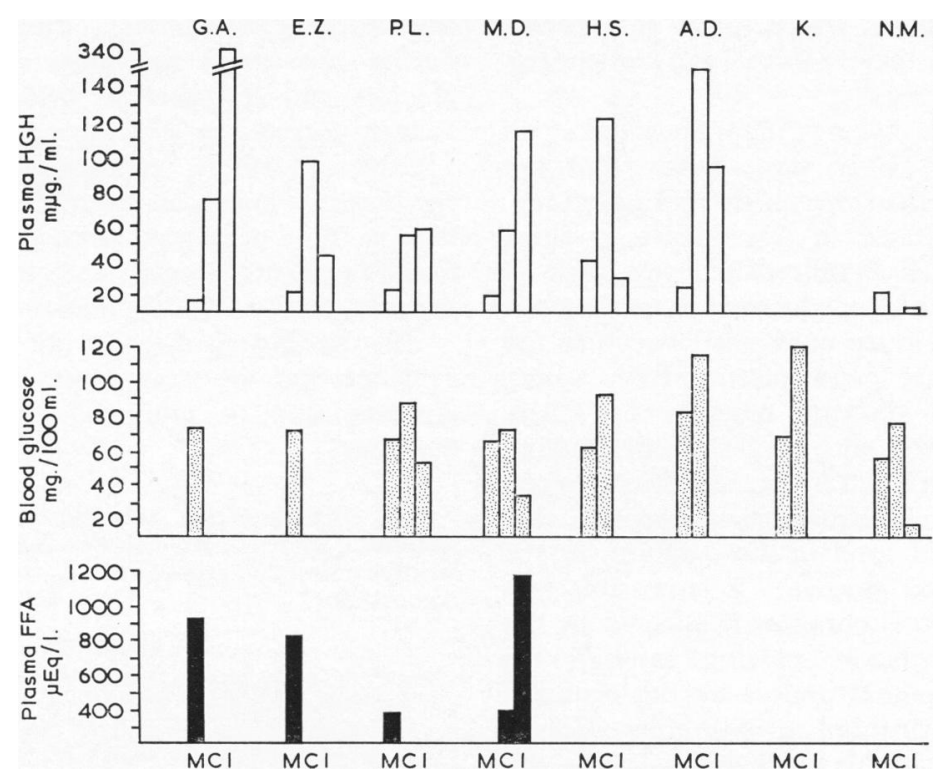

Frg. 3.-Plasma growth hormone (HGH), glucose, and free fatty acids in women with toxaemia of pregnancy at delivery, in the cord, and in the newborn infants.

\section{Discussion}

The fact that the plasma of the newborn infant contains a higher concentration of $\mathrm{HGH}$ (Cornblath et al., 1965) than does the plasma of the mother (Greenwood et al., 1964), indicates an active secretion of this hormone by the foetus. This hypothesis has recently been substantiated by showing that $\mathrm{HGH}$ is not transferred from the mother through the placenta (Gitlin, Kumate, and Morales, 1965; Laron, Mannheimer, Pertzelan, Goldman, and Guttmann, 1966). The role that growth hormone plays in the normal foetus and newborn infant is not clear, but the raised level could indicate an increased metabolic rate. The usual regulatory mechanism of growth hormone secretion found in adults, such as stimulation by hypoglycaemia and exercise and suppression by glucose administration (Glick, Roth,
Yallow, and Berson, 1965), does not seem to function adequately in the newborn (Cornblath $e t$ al., 1965). It was, therefore, of great interest to investigate the materno-foetal relation of growth hormone in diabetes and toxaemia, two states of hormonal and metabolic inbalance.

In the normal control group, the concentration of $\mathrm{HGH}$ in the cord plasma was twice that in the maternal plasma. This level was also raised as compared to the growth hormone concentration in normal women at rest, but consistent with increases noted during exercise or oestrogen stimulation (Frantz and Rabkin, 1965). In the normal newborn infant the mean HGH level doubled within several hours. This might be partly due to the marked decrease in blood glucose and would infer a normal regulatory mechanism. At the same time

IV

Blood of Mother, Cord, and Infant in Normal, Diabetic, and Toxaemic Pregnancies

\begin{tabular}{|c|c|c|c|c|c|c|c|c|}
\hline \multicolumn{3}{|l|}{ (mg./100 ml.) } & \multicolumn{6}{|c|}{ FFA $(\mu \mathrm{Eq} / \mathbf{l})}$. \\
\hline Cord & \multicolumn{2}{|c|}{ Infant } & \multicolumn{2}{|c|}{ Mother } & \multicolumn{2}{|c|}{ Cord } & \multicolumn{2}{|c|}{ Infant } \\
\hline Mean \pm S.E. & No. & Mean \pm S.E. & No. & Mean \pm S.E. & No. & Mean \pm S.E. & No. & Mean \pm S.E. \\
\hline $\begin{array}{l}81 \pm 12 \\
86 \pm 7 \cdot 7 \\
94 \pm 8 \cdot 1\end{array}$ & $\begin{array}{l}9 \\
6 \\
3\end{array}$ & $\begin{array}{l}47 \pm 4 \\
37 \pm 10 \\
36 \pm 10\end{array}$ & $\begin{array}{l}6 \\
8 \\
3\end{array}$ & $\begin{array}{l}1130 \pm 83 \\
1139 \pm 41 \\
713 \pm 160^{\star}\end{array}$ & $\begin{array}{l}8 \\
3 \\
1\end{array}$ & $\begin{array}{l}364 \pm 34 \\
377 \pm 99 \\
400\end{array}$ & $\begin{array}{l}8 \\
1 \\
1\end{array}$ & $\begin{array}{l}1195 \pm 200 \\
761 \\
1180\end{array}$ \\
\hline
\end{tabular}


the plasma FFA tripled, which could be a consequence of the rise in HGH (Raben and Hollenberg, 1960).

In the women with diabetes, all of whom received insulin, the plasma HGH was slightly, but not significantly, higher than that in the normal group. Plasma growth hormone in the infants of these diabetic mothers was significantly lower than in normal infants, as was blood glucose. Even the mean $\mathrm{HGH}$ concentration in the cord was lower than the normal mean. The lower plasma FFA values found in babies of diabetic mothers by Chen, Adam, Laskowski, McCann, and Schwartz (1965), and in the one case studied by us, may be explained by the low HGH. It is interesting to speculate what causes the low HGH level in these babies, in the presence of low blood glucose. It is possible that foetal HGH secretion is chronically affected by the large amounts of glucose passing through the placenta from the mother and/or by the resulting state of foetal hyperinsulinism (Stimmler, Brazie, and O'Brien, 1964). This finding is certainly the first direct evidence that the large size of babies born to diabetic mothers is not caused by increased amounts of $\mathrm{HGH}$ from either the mother or the foetus.

In toxaemia of pregnancy, which is a state characterized by vascular changes and water and salt retention leading to raised blood pressure and oedema, we found significantly raised $\mathrm{HGH}$ levels in the women at delivery, in the cord blood, and in the newborn several hours after delivery. The latter values varied considerably so that the mean difference was not statistically significant. On the other hand, blood glucose and FFA were significantly lower in the mothers, with no obvious differences from the normal in the infants. Since the aetiology of toxaemia of pregnancy is still unknown, further investigations will have to be made before an explanation of these findings is reached.

\section{Conclusions}

The concentration of plasma growth hormone, glucose, and free fatty acids was studied in three groups of pregnant women, normal, diabetic, and toxaemic, at delivery and in their newborn infants. It was found that HGH levels in the mother were higher at delivery than in the normal fasting state, whereas in the infants they were 2 to 4 times higher than those of the mother. These findings occurred during concurrent reduction of the infant blood glucose, and are taken as evidence that HGH is actively secreted in the foetus and newborn infant.

Growth hormone concentration was found to be significantly lower in infants of diabetic mothers than in those of normal mothers. However, it was found to be much higher in both mother and infant in cases of toxaemia of pregnancy.

The findings presented are considered further evidence that the large babies of diabetic mothers are not due to increased secretion of growth hormone.

The authors wish to acknowledge the technical assistance of Miss R. Buczkowski. Professor B. Gans kindly granted permission to study patients in his department.

\section{REFRRENCES}

Chen, C. H., Adam, P. A. J., Laskowski, D. E., McCann, M. L., and Schwartz, R. (1965). The plasma free fatty acid composition and blood glucose of normal and diabetic pregnant women and of their newborns. Pediatrics, 36, 843.

Cornblath, M., Parker, M. L., Reisner, S. H., Forbes, A. E., and Daughaday, W. H. (1965). Secretion and metabolism of growth hormone in premature and full-term infants. $f$. clin. Endocr.: 25, 209.

Dole, V. P. (1956). A relation between nonesterified fatty acids in plasma and the metabolism of glucose. $\mathcal{~ f . ~ c l i n . ~ I n v e s t . , ~ 3 5 , ~} 150$.

Fairweather, D. V. I. (1965). Changes in serum non-esterified fatty acid levels in spontaneous and in oxytocin induced labour. f. Obstet. Gynaec. Brit. Cwlth, 72, 408.

Frantz, A. G., and Rabkin, M. T. (1965). Effects of estrogen and sex difference on secretion of human growth hormone. $\mathcal{F}$. clin. Endocr., 25, 1470.

Gitlin, D., Kumate, J., and Morales, C. (1965). Metabolism and maternofetal transfer of human growth hormone in the pregnant woman at term. ibid., $35,1599$.

Glick, S. M., Roth, J., Yalow, R. S., and Berson, S. A. (1965). The regulation of growth hormone secretion. Recent Progr. Hormone Res., 21, 241.

Greenwood, F. C., Hunter, W. M., and Klopper, A. (1964). Assay of human growth hormone in pregnancy at parturition and in lactation. Detection of a growth-hormone-like substance from the placenta. Brit. med. $\mathscr{F}$., 1, 22.

Laron, Z., and Mannheimer, S. (1966). Measurement of human growth hormone. Israel f. med. Sci., 2, 115.

- - Pertzelan, A., Goldman, J., and Guttmann, S. (1966). Lack of placental transfer of growth hormone. Acta endocr. $(K b h$.$) . In the press.$

,,--- , and Nitzan, M. (1966). Growth hormone levels in

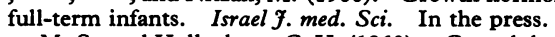

Raben, M. S., and Hollenberg, C. H. (1960). Growth hormone and the mobilization of fatty acids. In Human Pituitary Hormones. Ciba Foundation Colloquia on Endocrinology, ed. G. E. W. Wolstenholme and C. M. O'Connor, vol. 13, p. 89 . J. \& A. Churchill, London.

Stimmler, L., Brazie, J. V., and O'Brien, D. (1964). Plasma-insulin levels in the newborn infants of normal and diabetic mothers. Lancet, $1,137$.

Yen, S. S. C., Pearson, O. H., and Stratman, S. (1965). Growth hormone levels in maternal and cord blood. f. clin. Endocr., 25, 655. 